
D:\Nsurg \Vol. 23, No. 4, Oct. - Dec., 2019\Nsurg-10.Doc
(A)
P. $288-293$
III

ORIGINAL ARTICLE

\title{
Outcome of Endoscopic Third Ventriculostomy: An Experience of 80 Treated Patients
}

\author{
MUMTAZ ALI, ${ }^{1}$ AKRAM ULLAH, ${ }^{1}$ SAJID KHAN, ${ }^{1}$ ZUBAIR BASHIR, ${ }^{1}$ RAMZAN HUSSAIN ${ }^{2}$ \\ ${ }^{1}$ Prime Teaching Hospital and ${ }^{2}$ Irfan General Hospital, Peshawar - Pakistan \\ DOI: https://doi.org/10.36552/pjns.v23i4.384
}

\begin{abstract}
Objective: To examine the outcome of Endoscopic Third Ventriculostomy in 80 consecutive patients operated in Irfan General Hospital and Prime Teaching Hospital Peshawar.

Materials and Methods: Prospective observational study was conducted in the neurosurgery department of Prime Teaching Hospital and Irfan General Hospital Peshawar. 80 patients (48 male and 32 female) were followed for 3 months. The inclusion criteria all patients with Third ventricular hydrocephalus were included in this study and the exclusion criteria unwilling patients and those who opted for VP shunting rather than ETV. Data was analyzed using SPSS version 22.

Results: ETV was performed in 80 patients. With highest success rate inAqueductal stenosis and posterior fossa tumors $88 \%$ and $87 \%$ respectively. ETV had a lowest success score of 50\% in patients with Hydrocephalus TBM. Common post-operative complications were seizures and CSF leakage.

Conclusion: ETV is less invasive and effective treatment for non-communicating hydrocephalus.ETV is most effective in treating aqueductal stenosis and posterior fossa tumors. The overall success rate of ETV is $74 \%$. Based on these findings, it is recommended that ETV should be attempted as first line treatment for patients with triventricular hydrocephalus due to various pathologies.
\end{abstract}

Keywords: ETV (Endoscopic Third Ventriculostomy), communicating hydrocephalus, Posterior fossa tumors, Aqueductal stenosis.

\section{INTRODUCTION}

Hydrocephalus is one of the commonest neurological entity ${ }^{\cdot 1}$ It is the dilatation of ventricular system due to the imbalance of cerebrospinal fluid production and absorption. ${ }^{2}$ The common causes of hydrocephalus are congenital, infectious, post-traumatic and tumors. Congenital hydrocephalus is common due to aqueductal stenosis. ${ }^{3}$ In developing countries tuberculous meningitis (TBM) is one of the common cause of hydrocephalus. ${ }^{1}$ The common signs and symptoms of hydrocephalus are those of raised Intracranial pressure (ICP). That is headache, vomiting, blurring of vision or in severe causes decreased levels of conciseness. ${ }^{4}$ Commonly diagnosed on CT brain and MRI where dilation of ventricular system. ${ }^{5}$
For a long time, the only treatment for Hydrocephalus was ventriculoperitoneal shunting and other diversion procedures. ${ }^{6}$ Endoscopic Third Ventriculostomy is a surgical procedure used to treat hydrocephalus. In this procedure a stoma is made in the floor of third ventricle tuber cinereum using an endoscope. ${ }^{6,7}$ The first choice of noncommunicating hydrocephalus is ETV. Endoscopic Third Ventriculostomy is successful in patients with less elevated intracranial pressure and patients having success score. ${ }^{8-10}$

\section{MATERIALS AND METHODS Study Design}

A prospective observational study was conducted in 
the neurosurgery department of Prime Teaching Hospital and Irfan General Hospital Peshawar. Study duration was from January 2017 to December 2018.

\section{Inclusion Criteria}

80 patients were considered in this study. 76 were with obstructive hydrocephalus and 4 cases of communicated hydrocephalus brain tuberculosis.

\section{Exclusion Criteria}

Recurrent cases and those who refused consent due to were excluded from the study.

\section{Data Collection}

After taking consent from the patients, data was analyzed for all patients who underwent Endoscopic Third Ventriculostomy irrespective of the etiological type of hydrocephalus.

After admitting the patient procedure and prognosis based on Endoscopic Third Ventriculostomy success score written informed consent is taken. Under general anesthesia patient is positioned supine. After scrubbing and draping, a single burr hole was made over theKocher's point ( $3 \mathrm{~cm}$ lateral to the midline and $1 \mathrm{~cm}$ anterior to the coronal suture). The dura was opened in linear fusion. Endoscopetrocar was introduced and an endoscope was inserted. Following choroid plexus of the lateral ventricles foramen of Monro was reached Tuber cinereum and mammillary bodies were identified. A stoma was made at tuber cinereum with ventriculostomy catheter and kept the patient with a ballooned Fogarty catheter. After this, an endoscope was removed and the dura was closed with silk 4/0 interrupted stitches. Pericranium and wound were also closed with interrupted $2 / 0$ Vicryl and 2/0 Prolene respectively. ${ }^{1,6,11}$

ETV also has some complications, the most common of which are neurovascular injury, cerebrospinal fluid leakage, fever and superficial wound infection, intra cerebral hematoma, seizures altered consciousness and memory disturbance. ${ }^{12,13}$

The data was analyzed for signs/symptoms, diagnosis, MRI/CT brain pre-operative findings and early post-operative course was studied. These patients were followed for 3 months for any improvement in signs and symptoms. CT brain was done to see improvement in resolutionof hydrocephalus. All patients with Third ventricular hydrocephalus due to idiopathic aqueductal stenosis, most of the posterior fossa tumor, pineal tumor and ICH who were treated in this period were included in this study. All unwilling patients and those who opted for VP shunting rather than ETV were excluded from the study.

\section{Data Analysis}

Data was analyzed using SSPS version 22 and presented in form tables and charts.

\section{RESULTS}

\section{Gender Distribution}

In this study total 80 patients were included out of which 48 were male and 32 were female.

\section{Age Incidence}

Age of patients ranged from 6 months to 60 years. Most posterior fossa tumor patients were young having age range from 4 to 16 years. Pineal tumor patients were from 50 to 65 years. 2 patients with subarachnoid hemorrhage had the age of 47 and 60 respectively (Table 2).

\section{Clinical Presentation}

All patients were diagnosed with raised ICP due to HCP and were considered for ETV surgery. The patients presented with common signs and symptoms were mostly that of raised ICP. 72 patients (90\%) were presented with headache and vomiting, 36 patients (45\%) had papilledema , 4 patients (5\%) had lower cranial nerve palsy, 2 patients $(2.5 \%)$ had abducens nerve palsy, only 1 patients $(1.25 \%)$ had confusion, 3 patients $(3.75 \%)$ had optic nerve compression and 20 patients $(25 \%)$ had ataxia (Table 1$)$.

Table 1: Clinical Features.

\begin{tabular}{|l|c|}
\hline Clinical Features & Number \& \% of Patients \\
\hline Headache/Vomiting & $72(90 \%)$ \\
\hline Papilledema & $36(45 \%)$ \\
\hline Lower Cranial Nerve palsy & $4(5 \%)$ \\
\hline Abducent Nerve Palsy & $2(2.50 \%)$ \\
\hline Confusion & $1(1.20 \%)$ \\
\hline Optic nerve compression & $3(3.75 \%)$ \\
\hline Ataxia & $20(25 \%)$ \\
\hline
\end{tabular}


Table 2: Individual success percentage of ETV.

\begin{tabular}{|c|c|c|c|c|c|c|c|c|}
\hline \multicolumn{2}{|c|}{ Etiology } & \multirow{2}{*}{$\begin{array}{c}\begin{array}{c}\text { No. of } \\
\text { Patients }\end{array} \\
26\end{array}$} & \multirow{2}{*}{$\begin{array}{l}\text { Male } \\
15\end{array}$} & \multirow{2}{*}{$\begin{array}{c}\text { Female } \\
11 \\
\end{array}$} & \multirow{2}{*}{$\begin{array}{c}\text { Age } \\
1.5 \\
\text { years } \\
\end{array}$} & \multirow{2}{*}{$\begin{array}{l}\begin{array}{c}\text { Clinical } \\
\text { Features }\end{array} \\
\text { Raised } \\
\text { ICP } \\
\end{array}$} & \multirow{2}{*}{$\begin{array}{l}\begin{array}{c}\text { CT/MRI } \\
\text { Brain }\end{array} \\
10 \mathrm{CT}, 19 \\
\text { MRI }\end{array}$} & \multirow{2}{*}{$\begin{array}{c}\begin{array}{c}\text { Success } \\
\%\end{array} \\
88\end{array}$} \\
\hline $\begin{array}{l}\text { Aqueductal } \\
\text { stenosis }\end{array}$ & & & & & & & & \\
\hline \multirow{4}{*}{$\begin{array}{l}\text { Posterior fossa } \\
\text { tumors }\end{array}$} & $\begin{array}{l}\text { Cerebellar } \\
\text { astrocytoma }\end{array}$ & 3 & 2 & 1 & $\begin{array}{l}25.5 \\
\text { years }\end{array}$ & $\begin{array}{l}\text { Raised } \\
\text { ICP }\end{array}$ & $3 \mathrm{CT}$ & \multirow{4}{*}{87} \\
\hline & $\begin{array}{l}\text { Brain Stem } \\
\text { astrocytoma }\end{array}$ & 4 & 3 & 1 & 19 years & $\begin{array}{l}\text { Raised } \\
\text { ICP }\end{array}$ & $1 \mathrm{CT}, 3 \mathrm{MRI}$ & \\
\hline & $\begin{array}{l}\text { Ependymoma } \\
\text { post, fossa }\end{array}$ & 8 & 5 & 3 & $\begin{array}{l}14.5 \\
\text { years }\end{array}$ & $\begin{array}{l}\text { Raised } \\
\text { ICP }\end{array}$ & $2 \mathrm{CT}, 6 \mathrm{MRI}$ & \\
\hline & Medulloblastoma & 15 & 9 & 6 & 7 years & $\begin{array}{l}\text { Raised } \\
\text { ICP }\end{array}$ & $\begin{array}{l}5 \mathrm{CT}, 10 \\
\text { MRI }\end{array}$ & \\
\hline $\begin{array}{l}\text { CP angle } \\
\text { Tumors }\end{array}$ & & 10 & 7 & 3 & $\begin{array}{l}24.5 \\
\text { years }\end{array}$ & $\begin{array}{l}\text { Raised } \\
\text { ICP }\end{array}$ & $2 \mathrm{CT}, 5 \mathrm{MRI}$ & 70 \\
\hline Pineal Tumors & & 6 & 2 & 4 & 56 years & $\begin{array}{l}\text { Raised } \\
\text { ICP }\end{array}$ & $1 \mathrm{CT}, 2 \mathrm{MRI}$ & 70 \\
\hline $\begin{array}{l}\text { Hydrocephalus } \\
\text { TBM }\end{array}$ & & 4 & 2 & 2 & $\begin{array}{c}4.5 \\
\text { years }\end{array}$ & $\begin{array}{l}\text { Raised } \\
\text { ICP }\end{array}$ & $4 \mathrm{MRI}$ & 50 \\
\hline $\begin{array}{l}\text { Intraventricular } \\
\text { Hemorrhage }\end{array}$ & $\begin{array}{l}\text { Subarachnoid } \\
\text { hemorrhage }\end{array}$ & 2 & 1 & 1 & 55 years & $\begin{array}{l}\text { Raised } \\
\text { ICP }\end{array}$ & $3 \mathrm{CT}, 4 \mathrm{MRI}$ & 70 \\
\hline Colloid cyst & & 2 & 2 & 0 & 23 years & $\begin{array}{l}\text { Raised } \\
\text { ICP }\end{array}$ & $2 \mathrm{CT}$ & 80 \\
\hline
\end{tabular}

The major tool of investigation as radiological investigation in $47 \%$ patients was the Brain CT and in $85 \%$ of patients, the MRI brain alone or after CT brain was done. Majority of Patients were diagnosed with Hydrocephalus (26 patients) due to aqueductal stenosis and post fossa tumor (30 patients) while $\mathrm{CP}$ angle Tumors were 14 patients and 6 patients had pineal tumor.

All patients were operated on the elective list except 10 patients who were operated in an emergency. $1.2 \%$ (10 patients) had a low level of consciousness. All cases had triventricular Hydrocephalus except 4 patients who had communicating hydrocephalus due to tuberculous meningitis.

Simple ETV was performed in majority of the cases. In all patients with pineal tumor, the biopsy was taken along with ETV.However, in one patient with pineal tumor biopsy could not be taken due to bleeding, while in 2 patients with colloid cyst ETV was performed along with septum pellucidotomy. CSF for $\mathrm{R} / \mathrm{E}$ and culture was sent for patient with TBM. In pineal tumor patients CSF was taken for tumor markers.

Table 3: Peri-operative Complication.

\begin{tabular}{|c|c|c|}
\hline \multicolumn{2}{|c|}{ Peri-operative Complication } & $\begin{array}{c}\text { N. of } \\
\text { Patients }\end{array}$ \\
\hline \multicolumn{2}{|c|}{ Bleeding clinically insignificant } & 6 \\
\hline \multicolumn{2}{|c|}{ Bleeding clinically significant } & 1 \\
\hline \multirow{2}{*}{$\begin{array}{l}\text { Insignificant trauma } \\
\text { to neural structures }\end{array}$} & Mammillary body & 2 \\
\hline & Fornix & 1 \\
\hline
\end{tabular}

During surgery, total 7 patients had bleeding 2 patients were of pineal tumor where bleeding started after taking biopsy, 2 patients had colloid cyst, 2 with aqueductal stenosis and one having an intraventricular hemorrhage. In one patient, an extra ventricular drain was placed. In event of bleeding we thoroughly irrigate with a ringer lactate solution and usually 
bleeding subsides. Post operatively 3 patients had a memory problem due to fornix injury in one and mammillary body injury in 2 patients (Table 3 ).

Post-operatively, 4 patients had CSF leakage, while 5 patients had seizures, 2 patients had superficial infection of wound and one patient had an intracerebral hematoma. One patient could not be attempted due to excessive bleeding (Table 4).

Table 4: Post-operative Complications.

\begin{tabular}{|l|c|}
\hline Post-operative Complications & No. of patients (\%) \\
\hline Seizures & $5(6 \%)$ \\
\hline CSF leakage & $4(5 \%)$ \\
\hline Superficial Infectious Wound & $2(2 \%)$ \\
\hline Intra Cerebral hematoma & $1(1 \%)$ \\
\hline
\end{tabular}

All these patients were followed for 3 months. 71 patients $(88 \%)$ were symptomatically improved post operatively. The patients not improved include 2 patients of TBM and 4 patients of posterior fossa tumor with previous VP shunting. 3 patients were those of aqueductal stenosis having age of 3 to 7 months. Overall, the ETV procedure was successful in 71 patients (88\%) and in 9 patients $(11 \%)$ it was unsuccessful with no improvement.

\section{DISCUSSION}

Mostly preferred surgical procedure for noncommunicating hydrocephalus is ETV. In this procedure an endoscope is introduced into the ventricular system and the floor of the third ventricle is perforated to make a communication with prepontine cistern. ${ }^{6,14,15}$

In our study, the ETV was performed for different pathologies causing hydrocephalus. Patient having aqueductal stenosis ware 32\% (26 patients) posterior fossa tumor patient were $37 \%$ (30 patients) and few other conditions mention in table 2 . In our study the success rate of ETV for aqueductal stenosis is $88 \%$ as compared to a study done in the neurosurgery department, university of MAINZ, Germany having success rate of $81 \% .^{6}$ The slight difference is due to patient population with our study, we attempted ETV in patients with aqueductal stenosis, posterior fossa, Pineal tumor, etc. while in their study, the spectrum of disease is wide including cerebellum infarction, vein of galen malformation, metastasis and lymphomas etc.

In our patients, the success rate of ETV in pineal tumor patients was $70 \%$ as compared to the success rate of $100 \%$ in a study done at the university hospital of Toulouse. ${ }^{16}$ The difference in result is because our patients were less in number as compared to their study.In all these patients ETV was followed by biopsy of the tumor during which two patients had bleeding. In one of these patients extra ventricular drain was placed. These factors have affected the outcomes in these patients.

The success rate of posterior fossa tumor in our study was $87 \%$ as compared to study done at The Children Hospital, Pittsburgh which was $84 \%$, which is comparable. ${ }^{17}$ In the department of Neurosurgery, University of Utah, School of Medicine, 3\% (1 patient) have CSF leakage as compared to our study having patients with CSF leakage 5\% (4 patients) which is acceptable.

The incidence of infection in the above study is $3 \%$ ( 1 patient) while in our study it is $2 \%$ ( 2 patients) which is comparable. The overall complications in the above study are $14 \%$ as compared to our study $15 \%$. In our study, one patient could not be attempted due to excessive bleeding, while in the comparable study, there is 1 unsuccessful ETV procedure. ${ }^{18}$

\section{CONCLUSION}

ETV is less invasive and effective treatment for noncommunicating hydrocephalus.The success rate of ETV is highest in aqueductal stenosis and posterior fossa tumors while lowest in Hydrocephalus TBM. The overall success rate of ETV is $74 \%$. The most common post-operative complications are seizures and CSF leakage. Based on these findings, it is recommended that ETV should be attempted as first line treatment for patients with triventricular hydrocephalus due to various pathologies.

\section{REFERENCES}

1. Aranha A, Choudhary A, Bhaskar S, Gupta L. A randomized study comparing endoscopic third ventriculostomy versus ventriculoperitoneal shunt in the management of hydrocephalus due to tuberculous meningitis. Asian journal of neurosurgery, 2018; 13 (4): 1140 .

2. Kahle KT, Kulkarni AV, LimbrickJr DD, Warf BC. Hydrocephalus in children. The Lancet. 2016; 387 (10020): 788-99.

3. Warf BC, Collaboration EANR. Pediatric 
hydrocephalus in East Africa: prevalence, causes, treatments, and strategies for the future. World neurosurgery, 2010; 73 (4): 296-300.

4. Kirkpatrick M, Engleman H, Minns R. Symptoms and signs of progressive hydrocephalus. Archives of disease in childhood, 1989; 64 (1): 124-8.

5. Dinçer A, Özek MM. Radiologic evaluation of pediatric hydrocephalus. Child's Nervous System, 2011; 27 (10): 1543.

6. Hopf NJ, Grunert P, Fries G, Resch KD, Perneczky A. Endoscopic third ventriculostomy: outcome analysis of 100 consecutive procedures. Neurosurgery, 1999; 44 (4): 795-804.

7. Drake JM. Endoscopic third ventriculostomy in pediatric patients: the Canadian experience. Neurosurgery, 2007; 60 (5): 881-6.

8. Gianaris TJ, Nazar R, Middlebrook E, Gonda DD, Jea A, Fulkerson DH. Failure of ETV in patients with the highest ETV success scores. Journal of Neurosurgery: Pediatrics, 2017; 20 (3): 225-31.

9. Warf BC, Mugamba J, Kulkarni AV. Endoscopic third ventriculostomy in the treatment of childhood hydrocephalus in Uganda: report of a scoring system that predicts success. Journal of Neurosurgery: Pediatrics, 2010; 5 (2): 143-8.

10. Kulkarni AV, Riva-Cambrin J, Browd SR. Use of the ETV Success Score to explain the variation in reported endoscopic third ventriculostomy success rates among published case series of childhood hydrocephalus. Journal of Neurosurgery: Pediatrics, 2011; 7 (2): 143-6.

11. Jones R, Stening W, Brydon M. Endoscopic third ventriculostomy. Neurosurgery, 1990; 26 (1): 86-92.

12. Schroeder HW, Niendorf W-R, Gaab MR. Complications of endoscopic third ventriculostomy. Journal of neurosurgery, 2002; 96 (6): 1032-40.

13. Jung T-Y, Chong S, Kim I-Y, Lee JY, Phi JH, Kim S$\mathrm{K}$, et al. Prevention of complications in endoscopic third ventriculostomy. Journal of Korean Neurosurgical Society, 2017; 60 (3): 282.

14. Wright Z, Larrew TW, Eskandari R. Pediatric Hydrocephalus: Current State of Diagnosis and Treatment. Pediatrics in review, 2016; 37 (11): 478-90.

15. Fritsch MJ, Kienke S, Ankermann T, Padoin M, Mehdorn HM. Endoscopic third ventriculostomy in infants. Journal of Neurosurgery: Pediatrics, 2005; 103 (1): 50-3.

16. Sacko O, Boetto S, Lauwers-Cances V, Dupuy M, Roux F-E. Endoscopic third ventriculostomy: outcome analysis in 368 procedures. Journal of Neurosurgery: Pediatrics, 2010; 5 (1): 68-74.

17. Scarrow AM, Levy EI, Pascucci L, Albright AL. Outcome analysis of endoscopic III ventriculostomy. Child's Nervous System, 2000; 16 (7): 442-4.

18. Amini A, Schmidt RH. Endoscopic third ventriculostomy in adult patients. Neurosurgical focus, 2005; 19 (6): 1-6.

\section{Additional Information}

Disclosures: Authors report no conflict of interest.

Ethical Review Board Approval: The study was conformed to the ethical review board requirements.

Human Subjects: Consent was obtained by all patients/participants in this study.

Conflicts of Interest:

In compliance with the ICMJE uniform disclosure form, all authors declare the following:

Financial Relationships: All authors have declared that they have no financial relationships at present or within the previous three years with any organizations that might have an interest in the submitted work.

Other Relationships: All authors have declared that there are no other relationships or activities that could appear to have influenced the submitted work.

Correspondence: Dr. Akramullah

Prime Teaching Hospital Peshawar Medical College

Email.akramullah@hotmail.com 


\begin{tabular}{|c|c|c|c|}
\hline \multicolumn{4}{|c|}{ AUTHORSHIP AND CONTRIBUTION DECLARATION } \\
\hline Sr.\# & Author's Full Name & Intellectual/Contribution to Paper in Terms of: & \\
\hline 1. & $\begin{array}{l}\text { Mumtaz Ali } \\
\text { (Main/Principal Author). }\end{array}$ & $\begin{array}{l}\text { 1. Proposed topics and Basic Study Design, } \\
\text { methodology. }\end{array}$ & \\
\hline 2. & $\begin{array}{l}\text { Akram Ullah } \\
\text { (2nd Author) }\end{array}$ & 2. Data collection and calculations & $\begin{array}{l}\text { Signature by the } \\
\text { author(s) }\end{array}$ \\
\hline 3. & $\begin{array}{l}\text { Sajid Khan } \\
\text { (3rd Author) }\end{array}$ & 3. Analysis of data and interpretation of results etc. & \\
\hline 4. & $\begin{array}{l}\text { Zubair Bashir } \\
\text { (4th Author) }\end{array}$ & 4. Literature review and manuscript writing & \\
\hline 5. & $\begin{array}{l}\text { Ramzan Hussain } \\
\text { (5th Author) }\end{array}$ & $\begin{array}{l}\text { 5. Paper writing, referencing, Data Calculations and } \\
\text { quality insurer }\end{array}$ & \\
\hline
\end{tabular}

Date of Submission: 10-11-2019

Date of Revision: 02-12-2019

Date of Online Publishing: 25-12-2019

Date of Print: 31-12-2019 